\title{
Erratum
}

\section{Taking sovereignty out of this world: space weapons and empire of the future - ERRATUM}

\author{
RAYMOND DUVALL AND JONATHAN HAVERCROFT
}

doi:10.1017/S0260210508008267, Review of International Studies, Volume 34, issue 4, Published by Cambridge University Press.

Regrettably, the abstract was missed out from the above publication (R Duvall and J Havercroft, 2008). The abstract as it should have appeared is given here:

\begin{abstract}
Programs to deploy weapons in orbital space have important implications for international relations. In this paper, we analyse the constitutive logic of three modes of space weaponisation currently being pursued by the US - space-based missile defense, space control, and force application from orbital space. We show that these technologies of killing, when bundled together, constitute a new form of centralised sovereign power in a context of de-territorialised sovereignty. This is a new type of international political society, which we call empire of the future, distinct from and more ominous than the de-centralised form of Empire theorised by Hardt and Negri and the modern expression of classical hegemony now widely debated in discussions of putative American empire.
\end{abstract}

Also, the contributor details were given incorrectly for Jonathan Havercroft. His correct biography is given here:

Jonathan Havercroft (PhD University of Minnesota 2006) is an Assistant Professor of Political Science at the University of Oklahoma. In addition to space weapons, his research interests include struggles over the recognition of indigenous rights under international law, and the historical transformation of the norm of state sovereignty.

Finally, we are sorry to say that a few typographical errors were included in footnote 40 , on page 765 . The last sentence should correctly read:

We are unable to explore that connection in depth in this article, but see Alexander Wendt and Raymond Duvall, 'Sovereignty and the UFO', Political Theory (August, 2008) and Jonathan Havercroft and Raymond Duvall, 'Critical Astropolitics,' in Natalie Borman and Mike Sheehan, eds, Securing Outer Space (London: Routledge, forthcoming). 